\title{
Problematics Accounting Practices for Islamic Households
}

\author{
Diah Ayu Gustiningsih' ${ }^{1}$, Mediaty $^{2}$, Alimuddin $^{3}$, Andi Kusumawati ${ }^{4}$ \\ \{diahdani57@gmail.com ${ }^{1}$, unhasmediaty@gmail.com ${ }^{2}$, alimuddin.febuh@gmail ${ }^{3}$, andikusumawati@fe.unhas.ac.id ${ }^{4}$ \} \\ STIE Tri Dharma Nusantara, Makassar, Indonesia ${ }^{1}$ \\ Faculty of Economics and Business, Hasanuddin University, Makassar, Indonesia ${ }^{2-4}$
}

\begin{abstract}
This study aims to determine the current household accounting in Islamic households and the problem is to determine the zakah of Islamic households. The study was conducted by conducting semi-structured interviews with 2 informants. The results showed that Islamic households still use mental accounting in doing household accounting. Information from mental accounting in Islamic households has not been able to meet the information needs of Islamic households in terms of zakah and inheritance. This is because there is no continuous recording and separation of ownership of shared assets.
\end{abstract}

Keyword:

mental accounting, islamic household

Article Received: 18 October 2020, Revised: 3 November 2020, Accepted: 24 December 2020

\section{Introduction}

Man was created to be devoted to his Creator, forming a household is also one form of behavioral reflection on the compliance of a Muslim, explained that by being married then someone has tried to perfect half of his religion. For the sake of avoiding human beings fall into the seduction of lust then marriage can be a way out for someone who is physically ready and mentally strong. Through the household one can feel the greatness of the Creator, so humans should be grateful for the pleasure of the command to settle down.

Before settling down, a person only has the responsibility for one person but when he is married, he is responsible for the whole household, both his wife and children. This responsibility is not only in the nature of man's creation for himself but also for each member of his family. Likewise in relation to a family's obedience relationship to their religion includes all family members, not just personal members. In the compilation of Islamic law explained that one of the goals of fostering households is for worship.

Various accounting studies in families that touch the household have been carried out, such as
[1], [2]. [3]part of the research always touches on the realm of accounting practices and functions in order to reduce the problems in the common household called domestic violence and divorce caused by economic problems faced by every household. From various studies it is illustrated that the purpose of the household is worship has not been fully met.

[4] stated that in the study of romantic literature, home is a place of rest, heaven for life, and a place to calm the heart, but in the home there is also a household, wherein there is a center of conflict where in the household production and consumptive processes occur. In addition, there is also the performance of rational practices in the form of an accounting process whose purpose is accountability. Accountability itself is theoretically closely related to responsibility [5], although it cannot be said that accountability is responsibility [6]. The responsibility of an entity that is carried out by the agent to the principal, in a positivistic view, the principal entity is the shareholder (entity theory) and the owner of the company (proprietary theory) while in the view of nonpositivism assume the principal is essentially God (Shariah'ate enterprise theory). 
Most of the research on household accounting conducts research on general households, with relatively similar problems namely in the function of accounting practices for household economic management, while no one has examined accounting practices on Islamic household issues relating to zakah and inheritance, given that one of the purposes of marriage is for worship, then is not zakah a part of worship that needs to be considered for its existence in the household. Thus to run zakah in the household also needed information related to household accounting. This information is important, because one of them is to determine the amount of zakah that must be issued by a Muslim family [7]. Obligation of tithe is what distinguishes the obligations of Islamic households with other households. Financial statements are a form of accountability to the Creator of the universe for the muamallah done, this is the ideal goal of the pragmatic of Islamic accounting, while the ideal goal is as a form of information source which will be used for decision making.

Departing from these objectives, the financial statements produced in Muslim families also have pragmatic goals and ideal goals. The benefits of the financial statements of Muslim families can also be used as supporting evidence, acting as a source of information on wealth and accounts receivable and debt in a family and its ownership, which can later complement the measurement of zakah. The problem that then arises is how is household accounting carried out in Islamic households today?, considering that every Islamic household has a different understanding and ability about accounting. And how is the process of determining the amount of zakah that households spend?

\section{Urgency Accounting of Islamic Households}

Economics considers households to be the basis for units of analysis in many social, microeconomic models that have an impact on macroeconomics and governance [8], not only in households in the broadest sense but also at the level of households living together with the same goals and meet all their needs together with family [9]. Islamic households are part of these households. According to the Kompilasi Hukum Islam [10] An Islamic household is the joining of two Muslims who are engaged in a marriage for the purpose of worship.Households that are run for religious purposes require accounting in them to help carry out the mandate in the household, with self-awareness that there is accountability in the afterlife of all activities during running a household in the world.

From time to time conventional accounting continues to grow very rapidly. Initially accounting was only used in companies, but over time accounting was also used in social institutions, [11] explained that in the context of modern accounting studies, accounting that was originally designed for companies could be equivalent to social institutions, and households are institutions social.

It's just that in its development, accounting in the household only developed conventionally, whereas on the other hand, there was a group of people who needed alternative accounting concepts which contained Islamic principles. In conventional household accounting there are no differences in rights and obligations between husband and wife, but in Islamic households husband and wife have different rights and obligations according to Islamic principles.

The next hope is that with Islamic household accounting there will be a sakinah, mawaddah warrahmah relationship between the two main actors in the household. As Islamic religion is considered as a science that brings rahmatan lilalamin, it is not only households that can be given mercy, but will also have an impact on macro, household or household is the micro part of a country, prosperous, peaceful and advanced households will reflect the community the same way.

Indonesia's population is largely Muslim, it can even be said that the largest Muslim population in the world is Indonesia. So naturally if the population of Muslim families in Indonesia is also large. A Muslim family is the union of two 
people in a household that is built and carried out, with Islamic values and teachings. Forming a household is also one form of obedience of a Muslim, by being married then someone has tried to perfect half of his religion.

Before settling down, a Muslim only has the responsibility for his own person but when he is married, a Muslim is responsible for his entire household, both his wife and children. This responsibility is not only in the nature of the creation of manuasia for himself but also for each member of his family. Likewise in relation to a family's obedience relationship to their religion includes all family members, not just personal members.

There are so many Islamic households that exist, but not those who seriously implement accounting records in their households, even some of whom have high knowledge in accounting but also do not carry out accounting processes for their households. [12] explains that there are many factors that cause every family not to apply accounting practices in their families, not only because of knowledge, because the results of their research on family accountants, and nonaccountants get results, that not only education factors but also caused by work status, geographical and mental elements possessed by couples in practicing accounting in the household.

Accounting records carried out in the family will have an impact both internally and externally. Internally it can affect the condition of the family itself, which is to build a sakinah, mawaddah and warrahmah family that is the dream of every household, besides that accounting activities in this household can help the family in improving Islamic life, whose existence in a community can be wrong one form of an advanced society, with good management so that the family is born from an educated generation, who can advance their society, an educated society will impact on the advancement of a country because of the resources and welfare that go through progress, [7].

[1] family welfare can be achieved by carrying out accounting practices because the benefits of accounting are as a means of control in debt planning and unfavorable expenses in the household that are beneficial for long-term planning. Several other studies also provide results about the benefits of such accounting for families that implement it, such as [13], [2] who also conduct research on household accounting and its benefits, in long-term decisions will also affect the generation of each family, especially in meeting the economic needs and proper education.

While the external impact if the Islamic family practices accounting, is the possibility of a reduction in the divorce rate in a country due to poor family financial management, in which several studies show that one of the factors in divorce is the economic welfare of the family [14]. Divorce is permissible but this case is the most hated by Allah SWT, said through the words of Rosulullah SAW. As Muslims, the purpose of marriage is to perfect half of their religion, if there is a divorce and one of the factors is weak financial management without accounting practices. If the measure of the welfare of a country is also measured by the welfare of its people, then divorce is not a problem because of poor family economic management needs to be overcome. Islam considers that accounting is a science that guides the people, in solving various problems. Allah SWT through his word gives instructions not to leave people alone, and an explanation appears to perform accounting activities or in the Qur'an called Muhasabah.

Accounting practices in a family are also related to zakah issued in a family, which is beneficial to the benefit of a nation, by supporting the economic fulfillment of the recipient of the zakah itself. In Islam itself, zakah is the third pillar. The amount of zakah received and distributed by both muzzaki itself and zakah institutions plays a very important role in reducing poverty in a country. Zakah is also a source of income in a country that with its existence will have implications for economic growth and equity. Besides the distribution of zakah is also an effort to get blessings from Allah [15]. 
Recording is done in the accounting process of a Muslim family can provide black, white and white evidence about financial management, and the problem of accounts receivable, income, and the amount of assets and ownership, all of which had influenced the amount of zakah that must be issued by every Muslim family. The impact caused if wrong in determining the amount of zakah will certainly also have an impact on the muzzaki itself and on the recipient.

The impact for muzzaki itself, when he is less in issuing zakah, it will be considered that the person has not made zakah because the provisions of zakah have been regulated in Islam, in this case does not mean the muzzaki has not performed religious compliance because of neglect in carrying out the third pillar of Islam namely tithe. Meanwhile, if more in spending zakah then the excess is considered the muzzaki also do alms. The impact for asnaf or groups that may receive zakah is that not all asnaf can receive their right to zakah, meaning that there are still asnaf who still live in a state of economic shortage, because they do not receive zakah distribution, at a macro level, doesn't that mean the reduction in the number of poor households decreases also the poverty rate in a country. Thus the impact of accounting practices in an Islamic household is huge.

\section{Research Methods}

This study uses a qualitative approach with an interpretive paradigm. Alternately, according to [16]. the interpretive paradigm is also called the phenomenological or naturalistic paradigm, although admittedly this is often confusing. The interpretive paradigm views social reality as something holistic, not separate from one another, complex, dynamic, full of meaning, and the relationship between phenomena is reciprocal, not causality.

The interpretive paradigm also views social reality as something dynamic, processed and full of subjective meanings. Social reality is nothing but social construction. Regarding human position, the interpretive paradigm views humans as conscious and intentional beings in action (intentional human being).

Humans are creators who create the world, give meaning to the world, are not limited to laws outside themselves, and create creators of meaning. Based on this view, all human actions or behaviors are not automatic and mechanical, or suddenly occur, but rather a choice which contains an interpretation and meaning. This study tries to look at the meaning behind mental accounting problems carried out by households in general when Islamic households also practice it.

\section{Discussion}

Accounting is carried out with the aim of producing financial information for interested parties. The results of the accounting process are financial statements, in which there is information that will be used to make decisions. In the household also the purpose of doing accounting practices is to make decisions based on accounting information in the household. One of the benefits of household accounting information is for the calculation of zakah payments to Islamic households.

In paying zakah to Islamic households financial information is needed for Islamic households. In general, every household conducts accounting practices, it's just that the accounting practices are still conventional, in practice what is presented is how much is the husband's income and how much is the wife's income, further information related to household assets, and information related to household debt. Presentation as usual is also done in filling annual tax returns. Thus actually for individual NPWP owners, they have done accounting for their households. While from the results of interviews conducted, it is found that there is no complete accounting practice such as a cycle made, but only in the form of records related to income and expenses that are stored. As well as transactions that exist only in memory, this is commonly known as mental accounting.

[13] says that mental accounting is an accounting recording system based solely on what 
they remember or a series of cognitive operations used by individuals and households, in coding, classifying, and analyzing the financial activities of their households. The tendency of households to only do mental accounting in household accounting, causing the information needs not fulfilled for the calculation of zakah in the household. Need information related to husband and wife's income to calculate income zakah, need information related to household assets separated according to their ownership to calculate zakah assets. One of mrs. Ais' , a housewife and company employee, said:

"...I only know how much my salary and my husband, then if the end of the month is matched with the rest and receipt and I ask the husband for what the money is (salary) .... if I use my money for my daily shopping needs and needs, but I do not note, just I ask, the rest stay in the account anyway...'

When asked more about the memory of his expenses a month ago he said he did not remember them, while when asked about his financial balance he remembered the amount and related assets and debts.

"....I remember saving my savings if I know my husband too, how much did I buy my car, and I remember that if there is my inheritance because I am the youngest child ... right if the custom is so the youngest child has its share ..."

Things that are not much different when asked to Mrs. Fatwa, a lecturer,

“ ... if my money is for daily needs, if my husband's money is for paying for houses and cars, ..... I have no notes, I just ask how much is left, is there any time? If it's not usual I ask my money if I use it, my husband too ... there's no asset if I say but my father said my part will be limited to just conversation".

Based on the information from the 2 informants, both of them only use mental accounting, considering income and expenses, and considering the assets and accounts payable of the household, but this mental accounting is only able to be remembered every month period for the following months, the informant does not remember clearly the expenditure. When asked about who how to pay zakah, the two mothers said different things, the fatwa mother paid herself for her income and so did her husband's zakah,

"....If I immediately remove the zakah, if my husband pays, he pays it himself.."

While the second informant, Mrs. Ais said,

".....I don't know if that's the important thing, just come out $2.5 \%$ each time I receive my salary, if there is gold ji (after being asked it is not enough Nisab), if I save my savings, but I don't know if I hit it or not, because I don't know I've never calculate the zakah, rarely do I count the new ji I take as necessary, except for the investment I remember the amount yes (after the researchers calculated it has reached zakah) ... ".

There is no problem in Zakah on income, because it is directly issued at the time of receipt of income / salaries while for zakah assets such as information from interviews there is no information recorded continuously making so there is no total amount of the balance of assets in the form of savings, which is because it is located in a different account . Thus mental accounting causes the information generated in the household, has not been able to meet the information on the needs of Islamic households in terms of zakah.

Zakah maal is borne by each owner of the property, the assets obtained from the combined income of husband and wife, there needs to be a separation based on the acquisition price, so this information is not possible to be met by households that use mental accounting. Mental accounting, at the present time, for husband and wife in working households, causes the existence of two sources of income that are mentally arranged for income and income, and then the remainder is separated based on the objectives to be achieved in several accounts, so that during these objectives it has not yet been achieved causing the household to be able to act irrationally by ignoring its zakah obligation, before the goal of separating the household money balance is reached. 
[7] shows that there is no separation for husband and wife balances while for the presentation income has been separated in the description of making simple household accounting, while from this balance which will later turn into assets that will be used as the basis for calculating the zakah maal when a nisab is reached and haul.

Apart from zakah in Islamic households, there is also inheritance in every household, Islam clearly regulates the distribution of inheritance but to share it also requires information related to the ownership of husband or wife's assets. In the interview results it was found that there are assets mixed in the account, as well as assets obtained from inheritance, there are also assets obtained from grants. Isn't it true that this matter needs to be clearly recorded in its ownership, because Islam also distinguishes the assets of a husband and the property of a wife:

"Men are in charge of women, because Allah hath made the one of them to excel the other, and because they spend of their property (for the support of women). So good women are the obedient, guarding in secret that which Allah hath guarded. As for those from whom ye fear rebellion, admonish them and banish them to beds apart, and scourge them. Then if they obey you, seek not a way against them. Lo! Allah is ever High, Exalted, Great..." (QS. An-Nisa:34) [17].

Accountability to the Islamic family is not only to every actor in it but also to the main principal, namely Allah, the assets in the household will also be accounted for. Negligence in accounting for household assets includes, recognition, measurement, presentation and disclosure of assets in the household, not only have an impact on the household itself, but also on other people, in every asset there are rights of others in it, and if negligent in remove it, then the accountability in the afterlife is ready to wait. This is confirmed in a hadith

"The two feet of the son of Adam will not move from near his Lord on the Day of Judgement until he is asked about five (matters):- 1) about his life - how he spent it; 2) about his youth - how he took care of it; 3) about his wealth - how he earned it; 4) and where he spent it; 5) and about that which he acted upon from the knowledge that he acquired." (HR. Tirmidzi).

\section{Conclusions and Recommendations}

Accounting is carried out with the aim of producing financial information for interested parties (Mulyadi, 2001) [17], in Islamic households, financial related information, whether in the form of income, expenses, assets, accounts payable, is needed to perform the zakah worship in the family. The information presented in the mental accounting of Islamic households has not been able to meet these needs, while other matters related to household accounting information, are also needed in inheritance issues. So we need an Islamic family accounting model that is able to meet these problems. An accounting model that separates husband's and wife's assets. Likewise with the balance in the household to be separated from the wife and husband.

\section{Reference}

[1] Northcott, Deryl dan Dollin. 2000, "Home Accountants: Exploring Their Practices". University of Manchester School of Accounting And Finance. Accounting, Auditing \& Accountability Journal. Vol .13 Iss 4 pp $475-501$

[2] Carnegie, Garry D, Stephen P.W. (2005). "Household Accounting In Australia: Prescription and practice from the 1820 s to the 1960s", Accounting, Auditing \& Accountability Journal. Vol. 20 Iss 2 pp. $210-236$

[3] Manurung, DTH. Sinton, J. 2013. "Urgensi Peran Akuntansi Dalam Rumah Tangga (Studi Fenomenologis Pada Dosen

- Dosen Akuntansi di Universitas Widyatama Bandung) jurnal Ilmiah Akuntansi dan Humanika Vol.3.No.Issn 2089-3310

[4] Stephen P. Walker Sue Llewellyn, (2000),"Accounting at home: some 
interdisciplinary

perspectives",

Accounting, Auditing \& Accountability Journal, Vol. 13 Iss 4 pp. 425 - 449 http://dx.doi.org/10.1108/09513579910270 $129 \mathrm{a}$

[5] Carman, Marina. 2005. Responsibility and Accountability in Theory and Practice : The Truth and Reconciliation Commission's Investigation of Human Rights Abuse in South Africa, Thesis. http://www.library.unsw.edu.au

[6] Mulgan, Richard. 2002. Comparing Accountability in the Public and Private Sectors, Australian Journal of Public Administration Vol 59 (1), page 87-97

[7] Mulyani,Sri.2018. Pentingnya Akuntansi Rumah Tangga dalam Meningkatkan Hidup Islami. EQUILIBRIUM: Jurnal Ekonomi Syariah Volume 6, Nomor 2, 206 $-216$

[8] Sulivan, Arthur, Steven M, Sheffrin. 2003. Economics : Principles in Action Upper Saddle River, New Jersey 07458: Pearson Prentice Hall. P.29

[9] Setyowati, Nur Eka. 2016. Perempuan, Strategi Nafkah dan Akuntansi Rumah Tangga. Al-Amwal, Jurnal Kajian Ekonomi dan Perbankan Syariah, Vol 8, no 1. Halaman 294-304

[10] Tim redaksi fokus media.2007. Kompilasi Hukum Islam. Fokusmedia, Bandung

[11] Roslender, R. 1992. Sociological Perspective on modern accountancy. London, Routledge

[12] Yulianti, Melia.2016. Akuntansi dalam Rumah Tangga : Study Fenomenologi pada Akuntan dan Non Akuntan. Jurnal Akuntansi dan Manajemen, Vol 11, no 2. Halaman 62-75

[13] De Bont, Werner dan Thaler. (1994). Financial Decision MakingIn Market and Firm: Behavorial Prespective. National Bureau Of Economic Research. No. 4777

[14] Krishna, A., Rofaida, R., \& Sari, M. (2010). Analisis Tingkat Literasi Keuangan di Kalangan Mahasiswa dan
Faktor-Faktor yang Mempengaruhinya (Survei pada Mahasiswa Universitas Pendidikan Indonesia). Proceedings of The 4th International Conference on Teacher Education; Join Conference UPI \& UPSI Bandung, Indonesia

[15] Alimuddin dan Ruslan, Muhammad .2016. Ideologi Akuntansi Islam. Penerbit: PT. Raja Grafindo Persada, Jakarta.

[16] Patton, Michael Quinn. 1990. Qualitative Evaluation and Research Methods. Newbury Park, London, New Delhi: Sage Publications.

[17] ................ 2001. Al Qur'an dan Terjemahannya. Percetakan Al Quranul Karim Kepunyaan Raja Fadh. Madina AlMunawwarah. 